Larysa Shaulska, Doctor of Economics, Professor, Vasyl' Stus Donetsk National University, 21, 600-richchia st., Vinnytsia, 21021, Ukraine, ORCID: 0000-0002-7919-6733 ResearcherID: AAJ-9677-2020

Oleksandr Tregubov, $\mathrm{PhD}$ in Economics, Associate Professor, Vasyl' Stus Donetsk National University, 21, 600-richchia st., Vinnytsia, 21021, Ukraine, ORCID: 0000-0002-0397-5570

ResearcherID: AAJ-9456-2020

\title{
FOREIGN EXPERIENCE OF INDUSTRY 4.0 CONCEPT DEVELOPMENT IN TOURISM
}

The necessity of modern information technologies in the field of tourism has been proved. Experience of the leading countries in the field of digitization of the tourism industry and introduction of the Tourism 4.0 concept are analysed. The tools that are used within the framework of the Tourism 4.0 concept are determined. The main world practices of making appropriate organizational decisions at different levels of management are identified. Their implementation will contribute to the development of digitization of the domestic tourism industry.

Keywords: Tourism 4.0; digitization; tourism industry; digital economy.

Relevance of research topic. Modern transformation processes in the world economy are characterized by the global introduction of computer technologies and formation of the information society. They are aimed at the development of the digital economy based on the results of the fourth industrial revolution and are capable of substantial changing the methods of business organization, ensuring the development of countries and increasing the competitiveness of both industry and individual business.

Paying attention to the rapid development of information and communication technologies and their comprehensive integration into manufacturing and business processes, scientists (Kraus, Holoborodko \& Kraus, 2018) define the global digital transformation of various industries, which are under the influence of ecosystems, and call it the Concept of Industry 4.0 (or Industry 4.0 concept). 
Industry 4.0 represents the evolution of technology in the industry, which integrates traditional manufacturing processes with the information and communication technologies and information systems of the corporation (Zhekalo, 2019, p. 58).

However, it should be noted that formation of the digital economy doesn't mean the corresponding transformation and technological changes in production and business processes of a single industry. It implies all spheres in total, including the social system of the society. Therefore, digitization and access to the relevant infrastructure are equally important for the service sector. The world tourism industry doesn't stay aside from these processes.

Thus, when introducing the modern information technology in the field of tourism and hotel business, the developed countries use actively the industry-specific approaches and experience, which contribute to the introduction of the Tourism 4.0 concept and make the topic of this study urgent.

Formulation of the problem. In Ukraine, the need to form the digital economy and society (Kontseptsiia rozvytku, n.d) is recognized at the state level.

Therefore, emphasizing the importance of the use of the potential of Industry 4.0, including the tourism sector, we should pay attention to the number of problems that hinder or make the appropriate processes impossible, namely:

underdevelopment of the regulatory framework governing the processes of the digital economy development;

lack of high internet penetration $(64.9 \%$ as of May 2018) (Dynamika korystuvannia Internet, 2017);

the existence of a gap between the availability of broadband Internet access in large cities and small villages;

insufficient level of the digital infrastructure development;

low level of the digital information protection;

lack of proper government support for organizations implementing digital technologies in the regions (even in the field of high-technology business and information and computer technologies) (Tsyfrova transformatsiia, 2018).

According to the research data, the leading countries of the world have effectively directed the opportunities of the fourth industrial revolution to the development of the digital economy and tourism in particular. Therefore, the current international experience in implementing the tools of the Tourism 4.0 concept is a serious material for studying, analysing and adapting in our country.

Analysis of the recent research and publications. The problems of the development of the modern digital economy are considered by Zhekalo H. (2019), Kraus N. M., Goloborodko O. P., Kraus K. M. (Kraus, Holoborodko \& Kraus, 2018).

The studies of Bogomazova I., Anopriyeva K., Klimova T. (Bogomazova, Anoprieva \& Klimova, 2019), Cherevichko T., Temyakova T. (Cherevichko. \& Temyakova, 2017) focus their attention to the problems of digitization of the tourism industry. 
However, in the context of the digitization of the economy and the tourism industry, in particular, the problems of studying the positive experience of other countries, as well as analysing the trends in its development, remain insufficiently researched and require deeper scientific study. This will ensure the implementation of the tools of the Tourism 4.0 concept. It will increase the competitiveness of the industry.

Tasks formulation. The purpose of the article is to analyse the experience of the leading countries in the digitization of the tourism industry and to introduce the concept of Tourism 4.0. To achieve the goal, the following tasks were set and solved: the world leaders in the field of digitization were identified; the tools introduced by countries in the context of the implementation of Concept 4.0 in the tourism industry were analysed; the basic world practices of decision-making at different levels of management were highlighted.

Synopsis of the material under the study. Taking into account the fact that digitization of the economy is an important prerequisite for the introduction of Concept 4.0, we consider it to be appropriate for identifying the potential of the world's leading countries in this field.

We state that the Global Index of Network Interaction (GINI) allows to explore the transition from the basic levels of networking to the up-to-date digital technologies (broadband networks, data processing centres, cloud services, big data and the Internet of Things). They also influence the economic growth.

It should be noted that the index compares 79 countries, which together make up $95 \%$ of the world GDP, by 40 indicators and allows to analyse the influence of information and communication technologies on the country's economy; to research the level of competitiveness in the field of digital technologies; identify the stage of the country on the way to transition to the digital economy and its future growth reserves (Table 1).

Table 1

Breakdown of the countries according to the Global Index of Network Interaction (2018 Leader Countries)

\begin{tabular}{|l|l|c|c|l|c|}
\hline$№$ & Country name & Rating & № & Country name & Rating \\
\hline 1 & the USA & 78 & 11 & South Korea & 64 \\
\hline 2 & Singapore & 75 & 12 & Australia & 64 \\
\hline 3 & Sweden & 73 & 13 & Luxemburg & 63 \\
\hline 4 & Switzerland & 71 & 14 & Germany & 63 \\
\hline 5 & Great Britain & 70 & 15 & New Zealand & 62 \\
\hline 6 & Finland & 68 & 16 & Ireland & 62 \\
\hline 7 & Denmark & 68 & 17 & Canada & 62 \\
\hline 8 & the Netherlands & 67 & 18 & Belgium & 61 \\
\hline 9 & Norway & 65 & 19 & France & 61 \\
\hline 10 & Japan & 65 & 20 & Austria & 60 \\
\hline
\end{tabular}

Source: Vyihod na novyiy uroven rosta s pomoschyu intellektualnogo setevogo vzaimodeystviya Shema perehoda $k$ tsifrovoy ekonomike s globalnyim indeksom setevogo vzaimodeystviya za 2018 god. Retrieved from https://www.itu.int/en/ITU-D/Regional-Presence/CIS/Documents/Events/2018/08_Issyk-Kul/Presentations/gci_ 2018_whitepaper_ru. pdf. [in Russian]. 
It should be noted that the top five GINI countries in 2018 include the United States, Singapore, Sweden, Switzerland and the United Kingdom, which have shown not only a high level of modern digitalization but also significant future potential that also creates the foundation for the relevant processes in the field of tourism.

Special attention should be drawn to the findings of researchers (Vyihod na novyiy uroven, 2018), who state that a one-point increase in the GINI will favour to the competitiveness increase by $2.1 \%$, innovations development by $2.2 \%$ and the increase of productivity in all sectors of economy by $2.3 \%$. Moreover, such a pattern can be traced regardless of the country's ranking.

The analysis of the US experience as the ranking leader shows that the development of the digital economy favours not only to creation of the next-generation manufacturing industries, but also to the constant improvement of the level of hightechnology services.

It should be said that digitization of the tourism industry and introduction of the Tourism 4.0 concept on the basis of digitized processes allows to combine the services provision and related technological processes, based on the introduction of the relevant services (intelligent systems), into a single technological system at different stages: from designing to direct receiving by the customer. Such approach allows to design a service-product system to meet the requirements of the specific market segments, or even individual customers.

Studying the experience of implementing the tools of the Tourism 4.0 concept allows to distinguish the following world practices, which can be interesting for domestic industry: introduction of the digital platforms that allow different parties to interact online. They are able to provide an integrated approach in dealing with the customers and provide for organization of flights, transfers, accommodation, etc. This ensures the solution of the problems at different levels and optimization of financial costs and time is achieved;

development of the Internet of Things technology that enables corporations to analyse tourists' preferences with regard to locations and the range of other factors of influence. The practical implementation of such research is possible due to use of mobile guides, tickets pay applications, virtual reality technologies, etc. (Bogomazova, Anoprieva, \& Klimova, 2019, p. 41);

the use of modern software applications, technical systems, chatbots that can quickly respond to the preferences of tourists, helps to search for places of interest (3D-modeling, webcams of tourist sites, implementation of QR codes, RFID tags);

implementation of sharing services that can take the relationship between the providers and consumers of tourist services to a new level. Offer Aggregators make it possible to compare prices, conditions and services rating made by other consumers. They help to choose the available options;

development of the «cloud services», which allow the staff of the travel agencies to carry out their work remotely, reduces the cost of renting premises (Voronkova, 2018, p. 50); 
the use of blockchain technologies to increase the level of trust, the reliability of booking and paying, to ensure the information reliability and feedback on the tourist services received.

However, the international practices prove that implementation of tools under the Tourism 4.0 concept requires appropriate organizational decisions at various management levels, including the governmental one. Among the most important the following should be picked out:

active use of startups to generate interesting ideas for the introduction of digitization tools in the tourism sector. It should be noted that implementation of such initiatives is encouraged not only by the leading countries, but also by those where the tourism industry contributes significantly to the development of the national economy (Sri Lanka, Indonesia, Laos, Thailand, etc.);

use of marketing communication tools to promote digital products in the industry, including the governmental level (Israel, Iceland, Germany, UAE and other countries);

international cooperation in the field of digitization of the industry, which is actively demonstrated by the countries of the European Union;

introduction of the Tourism 4.0 concept on the basis of the strategic approach, which is implemented by means of formulating an appropriate strategy at the state level. This enables the countries to achieve regulated tourism development and to implement innovations in relation to other sectors of the economy along the entire cost chain (transport, education, culture, etc.). Thailand and Turkey have also presented the Tourism 4.0 strategy.

Conclusion. It should be noted that digitization and change of the approaches to the tourism industry are able to ensure full interaction of participants of the economic activity, enable corporations to increase their scale, expand their target customers, improve the quality of service and gain additional competitive advantages.

The leading countries of the world directed the possibilities of the fourth industrial revolution to the development of the tourism industry. The study of the experience of implementing the tools of the Tourism 4.0 concept made it possible to summarize world practices and to identify not only the basic tools, but also the relevant organizational solutions implemented at various levels of management, including the governmental one.

It should be emphasized that studying the positive world experience of implementing the Tourism 4.0 concept and its adaptation to domestic conditions will allow to form a modern effective basis for forming an effective state policy in this field.

However, it should be stated that implementation of the experience requires appropriate adjustment of the legal basis, development of the appropriate infrastructure, and institutional transformations. These areas will be the prospects for further research. 


\section{REFERENCES}

1. Bogomazova, I. V., Anoprieva, E. V., Klimova, T. B. (2019). Tsifrovaya ekonomika $\mathrm{v}$ industrii turizma i gostepriimstva: tendentsii i perspektivyi. Servis $v$ Rossii i za rubezhom - Service in Russia and abroad, Vol.13, 3, 34-47. [in Russian].

2. Cherevichko, T. V. \& Temyakova, T. V. (2017). Tsifrovizatsiya turizma: formyi proyavleniya. Vestnik Sarat. un-ta. Seriya. Ekonomika. Upravlenie. Pravo Bulletin of Sarat. University. Series. Economy. Control. Right, Vol.19, 1, 59-64. [in Russian].

3. Tsyfrova transformatsiia (tsyfrovizatsiia) rehioniv ukrainy. Analitychna zapyska. Retrieved from http://academy.gov.ua/pages/dop/198/files/4ba4 c1b4-cefe4f27-b58b-3aee7c8cf152.pdf. [in Ukrainian].

4. Dynamika korystuvannia Internet v Ukraini: traven 2017. Retrieved from http://www.kiis.com.ua/?lang=ukr\&cat=reports\&id=705\&page=1. [in Ukrainian].

5. Kontseptsiia rozvytku tsyfrovoi ekonomiky ta suspilstva Ukrainy na $2018-$ 2020 roky. Retrieved from http://zakon3.rada.gov.ua/laws/show/67-2018-\%D1\%80 [in Ukrainian].

6. Koroleva, M. A. \& Kuscheva, N. B. (2018) Tsifrovaya ekonomika turizma i sferyi uslug kak «proryiv v buduschee». Vestnik industrii gostepriimstva: sbornik materialov - Hospitality Industry Bulletin: Compendium of Materials. (pp. 55-58). $\mathrm{SPb}$. [in Russian].

7. Kraus, N. M., Holoborodko, O. P., Kraus, K. M. (2018). Tsyfrova ekonomika: trendy ta perspektyvy avanhardnoho kharakteru rozvytku. Efektyvna ekonomika - Effective economy, Retrieved from http://www.economy.nayka. com.ua/pdf/1_2018/8.pdf. [in Ukrainian].

8. Voronkova, L. P. (2018). Internet kak informatsionnyiy resurs mezhdunarodnogo turizma. Informatsionnoe obschestvo - Information society, 2, 49-53. [in Russian].

9. Vyihod na novyiy uroven rosta $\mathrm{s}$ pomoschyu intellektualnogo setevogo vzaimodeystviya Shema perehoda $\mathrm{k}$ tsifrovoy ekonomike $\mathrm{s}$ globalnyim indeksom setevogo vzaimodeystviya za 2018 god. Retrieved from https://www.itu.int/en/ITUD/Regional-Presence/CIS/Documents/Events/2018/08_Issyk-Kul/Presentations/gci_ 2018_whitepaper_ru.pdf. [in Russian].

10. Zhekalo, H. (2019). Tsyfrova ekonomika Ukrainy: problemy ta perspektyvy rozvytku. Naukovyi visnyk Uzhhorodskoho natsionalnoho universytetu - Science News of Uzhgorod National University, (23), 56-61. [in Ukrainian]. 